\title{
Potensi Jamur Endofit terhadap Pertumbuhan dan Produksi Tanaman Cabai (Capsicum annum)
}

Potency of Endophytic Fungi against the Growth and the Production on Chili (Capsicum annum)

Yenni Marnita ${ }^{1 *}$, Lisnawita ${ }^{2}$ dan Hasanuddin ${ }^{2}$

${ }^{1}$ Prodi Agroteknologi Fakultas Pertanian Universitas Samudra Langsa

${ }^{2}$ Prodi Agroekoteknologi Program Pasca Sarjana Fakultas Pertanian USU

*Coresponden author: yennimarnita@yahoo.co.id

\begin{abstract}
ABSTRAK
Jamur endofit merupakan jamur yang hidup di dalam jaringan tanaman sehat tanpa menyebabkan gejala atau kerusakan pada tanaman inang. Penelitian ini bertujuan untuk menguji potensi jamur endofit terhadap pertumbuhan dan produksi tanaman cabai melalui metode aplikasi perendaman benih, perendaman akar, penyemprotan ke daun dan penyemprotan ke buah. Rancangan yang digunakan adalah Rancangan Acak Kelompok Faktorial dengan 2 faktor, 4 perlakuan dan 3 kali ulangan. Faktor pertama adalah cara aplikasi: perendaman benih (A1), perendaman akar (A2), penyemprotan pada daun (A3), dan penyemprotan pada buah (A4) sedangkan faktor kedua adalah asal isolat: tanpa isolat jamur endofit $\left(E_{0}\right)$, isolat jamur endofit dari akar cabai $\left(E_{1}\right)$, isolat jamur endofit dari batang cabai $\left(E_{2}\right)$, dan isolat jamur endofit dari buah cabai $\left(E_{3}\right)$. Aplikasi melalui perendaman akar dan penyemprotan daun dengan Penicillium sp. memberikan hasil yang baik terhadap pertumbuhan dan aplikasi melalui daun dengan Geotrichum sp. dapat meningkatkan produksi cabai, sehingga berpotensi untuk dikembangkan sebagai agens hayati.
\end{abstract}

Kata kunci : Jamur endofit, Penicillium sp., Rhizoctonia sp., Geotrichum sp.

\begin{abstract}
Endophytic fungi is a fungi that lives in healthy plant tissues without causing symptoms or damage on the host plant . This research aims to test the potential of endophytic fungi against the growth and production on chili through application methods of soaking seeds, soaking roots, spraying the leaves and spraying on fruit. The design used was a factorial randomized block design with 2 factors, 4 treatments and 3 repetitions. The first factor has the way applications: soaking seeds (A1), soaking roots (A2), spraying the leaves (A3), and spraying on fruit (A4). The second factor has the origin of isolates: without endophytic fungi isolates (E0), roots isolates of chili (E1), stem of chili (E2), and endophytic fungi isolates from chilies (E3). Applications through soaking roots and spraying the leaves with Penicillium sp. give good results on the growth and application through the leaves with Geotrichum sp. can increase the production of chili, so it has the potential tobe developed as a biological agents.
\end{abstract}

Keywords: Endophytic fungi, Penicillium sp., Rhizoctonia sp., Goetrichum sp.

\section{PENDAHULUAN}

Tanaman cabai merah (Capsicum annum, L) adalah salah satu komoditas penting yang dikenal sebagai penyedap dan pelengkap menu masakan khas Indonesia. Cabai merah mengandung berbagai macam senyawa yang berguna bagi kesehatan manusia. Cabai mengandung Lasparaginase dan Capsaicin yang berperan sebagai zat 
antikanker (Kilham, 2006). Secara umum tanaman cabai memiliki kandungan gizi dan vitamin di antaranya, protein, lemak, karbohidrat, kalsium, vitamin A, B1 dan vitamin C (Nurahmi et al., 2011). Berdasarkan hal tersebut cabai merupakan salah satu komoditas sayuran penting dan bernilai ekonomi tinggi di Indonesia yang dibudidayakan baik di dataran rendah maupun dataran tinggi.

Usaha untuk meningkatkan produksi tanaman cabai masih mengalami hambatan. Menurut Badan Pusat Statistik (2014), produktivitas cabai nasional Indonesia tahun 2014 adalah 8.16 ton per hektar. Angka tersebut masih sangat rendah jika dibandingkan dengan potensi produksinya yaitu 20 ton per hektar. Hasil produksi cabai tersebut sangat dipengaruhi oleh faktor cuaca dan serangan hama penyakit yang mampu menyebabkan produktivitas tanaman menurun bahkan menyebabkan gagal panen. Keadaan iklim Indonesia yang akhir-akhir ini tidak menentu dapat membuat pertumbuhan dan perkembangan tanaman terganggu sehingga tanaman tidak mampu berproduksi secara maksimal.

Pengembangan tanaman cabai di Indonesia juga masih mengalami beberapa kendala, yaitu berkaitan dengan kualitas benih, teknik budidaya, serangan hama dan penyakit, serta penggunaan varietas cabai yang memiliki daya hasil tinggi masih sulit diperoleh karena harga benihnya yang mahal (Kirana, 2006).

Upaya untuk meningkatkan pertumbuhan dan produksi tanaman cabai salah satunya adalah dengan pemanfaatan agens hayati. Salah satu sumber agens hayati tersebut adalah jamur endofit. Jamur endofit merupakan jamur yang hidup di dalam jaringan tanaman sehat tanpa menyebabkan gejala atau kerusakan pada tanaman inang (Petrini, 1991). Endofit dapat berperan sebagai perangsang pertumbuhan tanaman dan meningkatkan hasil melalui produksi fitohormon dan penyedia hara sebagai penetral kontaminan tanah sehingga meningkatkan fitoremidiasi, dan agens hayati. Magnani et al. (2010) menemukan Enterobacter, Kluyvera ascorbata SUD165 yang mampu merangsang pertumbuhan tanaman dan resisten terhadap logam berat.

Beberapa jamur endofit dapat memproduksi enzim seperti selulosa dan lignin, serta memproduksi senyawa metabolit sekunder seperti alkaloid, paxillin, lolitrems dan tetranone steroid sehingga memungkinkan digunakan untuk meningkatkan ketahanan tanaman terhadap penyakit (Strobel \&Daisy, 2003).

Pemanfaatan jamur endofit tersebut dapat dilakukan melalui beberapa metode aplikasi yaitu melalui perendaman benih, perendaman akar, penyemprotan ke daun dan penyemprotan ke buah. Hasil penelitian Nurhayati et al. (2012) aplikasi Trichoderma virens melalui penyemprotan pada daun dan penyiraman pada akar dapat menekan infeksi patogen downy mildew pada tanaman caisin, mampu memperpanjang periode inkubasi dan menekan jumlah dan luas bercak serta keparahan penyakit downymildew yang disebabkan oleh patogen downy mildew pada tanaman caisin. Siddiqui \& Shaukat (2003) menyatakan bahwa endofit memiliki banyak kelebihan sebagai agens hayati, yaitu mudah dibiakkan secara in vitro, mudah diaplikasikan, misalnya melalui biji, dapat mengurangi kerusakan akar lebih awal, terhindar dari kompetisi dengan mikroba lain dan memiliki kemampuan dalam mempengaruhi tanaman merespon serangan parasit, tidak menghasilkan racun terhadap tanaman, bahkan menghasilkan hormon perangsang tumbuh, dan tergantung terhadap eksudat akar dalam perkembangbiakannya. Kloepper et al.(1993), menambahkan jamur endofit memiliki keunggulan sebagai agens hayati yaitu mampu meningkatkan ketersediaan nutrisi, menghasilkan hormon pertumbuhan, dan mengendalikan penyakit 
tumbuhan, serta dapat menginduksi ketahanan tanaman.

Berdasarkan latar belakang dapat diketahui bahwa dalam tanaman terdapat jamur endofit yang memiliki manfaat yang sangat penting bagi tumbuhan. Simbiosis antara jamur endofit dengan tanaman cabai dapat digunakan sebagai agens hayati untuk meningkatkan pertumbuhan dan produksi tanaman cabai, hal ini juga berhubungan erat dengan metode aplikasi yang digunakan.

Penelitian ini bertujuan untuk menguji potensi jamur endofit terhadap pertumbuhan dan produksi tanaman cabai melalui metode aplikasi perendaman benih, perendaman akar, penyemprotan ke daun dan penyemprotan ke buah.

\section{BAHAN DAN METODE}

Penelitian dilaksanakan pada bulan Juni 2012 sampai dengan Mei 2014. Isolasi dan perbanyakan jamur endofit dilakukan di laboratorium Penyakit Tumbuhan Fakultas Pertanian Universitas Sumatera Utara Medan, sedangkan penelitian lapang dilaksanakan di Dusun Sentosa Desa Gampong Blang Kecamatan Langsa Kota, Kota Langsa, Provinsi Aceh.

Alat-alat yang digunakan dalam penelitian ini adalah laminar air flow cabinet, autoklaf, oven, cawan petri, jarum inokulasi, bunsen, kompor gas, pengaduk kaca, pinset, kertas saring, inkubator, aluminium foil, mikroskop, cover glass, gelas objek, gelas ukur, tabung reaksi, pipet volume, erlenmeyer, jangka sorong, botol media, shaker, sentrifugasi, timbangan analitik dan silet.

Bahan-bahan yang digunakan adalah biakan murni isolat dari akar (Penicillium sp.), batang (Rhizoctonia sp.) dan buah (Geotrichum sp.) tanaman cabai, benih cabe Lado F-1, natrium hipoklorit 1\%, akuadest, potato dextrose agar (PDA), etanol, dan sebagainya.
Metode penelitian menggunakan Rancangan Acak Kelompok (RAK) Faktorial dengan 2 faktor dan 3 kali ulangan.

Faktor Pertama ; cara aplikasi isolat endofit (A) terdiri dari 4 taraf, yaitu: $\mathrm{A}_{1}=$ perendaman benih cabai pada isolat endofit, $\mathrm{A}_{2}=$ perendaman akar cabai pada isolat endofit, $\mathrm{A}_{3}=$ penyemprotan isolat endofit ke daun cabai, $\mathrm{A}_{4}=$ penyemprotan isolat endofit ke buah cabai. Faktor kedua ; Asal isolat jamur endofit (E) terdiri dari 4 taraf, yaitu : $\mathrm{E}_{0}=$ Tanpa isolat jamur endofit (kontrol), $\mathrm{E}_{1}=$ Isolat jamur endofit dari akar cabai, $\mathrm{E}_{2}=$ Isolat jamur endofit dari batang cabai, $\mathrm{E}_{3}=$ Isolat jamur endofit dari buah cabai. Sehingga didapat 16 kombinasi perlakuan yaitu: A1E0=Perendaman benih tanpa jamur endofit, A1E1=Perendaman benih dengan Penicillium sp., A1E2=Perendaman benih dengan Rhizoctonia sp., A1E3= Perendaman benih dengan Geotrichum sp., A2E0 =Perendaman akar tanpa jamur endofit. A2E1=Perendaman akar dengan Penicillium sp., A2E2=Perendaman akar dengan Rhizoctonia sp., A2E3 =Perendaman akar dengan Geotrichum sp., A3E0= Penyemprotan ke daun tanpa jamur endofit, A3E1=Penyemprotan ke daun dengan Penicillium sp., A3E2=Penyemprotan ke daun dengan Rhizoctonia sp., A3E3=Penyemprotan ke daun dengan Geotrichum sp., A4E0=penyemprotan ke buah tanpa jamur endofit, A4E1=penyemprotan ke buah dengan Penicillium sp., A4E2=penyemprotan ke buah dengan Rhizoctonia sp., A4E3= penyemprotan ke buah dengan Geotrichum sp.

Pelaksanaan penelitian meliputi: Tanah untuk media tanam terlebih dahulu dibersihkan dari akar, rumput-rumputan, batu dan kerikil. Setelah itu tanah dicampur dengan pupuk kandang dengan perbandingan 2:1. Campuran tanah dan pupuk kandang tersebut kemudian disterilkan dengan cara dipanaskan di dalam tong pengukus selama 2 
jam. Setelah itu tanah steril siap digunakan. Benih yang akan digunakan didesinfeksi dahulu dengan larutan natrium hipoklorit $1 \%$ selama 2 menit, kemudian dibilas dengan akuades steril sebanyak tiga kali dan disemaikan pada media tanam steril (Istikorini, 2008) .

Lahan yang digunakan adalah rumah kasa dengan ukuran panjang $\mathrm{x}$ lebar $\mathrm{x}$ tinggi : $17 \times 6 \times 3$ m, atap rumah kasa terbuat dari plastik transparan yang tembus cahaya dan di sekelilingnya ditutupi dengan kain kasa yang halus guna mencegah masuknya serangga dan hama lainnya. Lahan yang digunakan terletak di dusun Sentosa desa Gampong Blang Kecamatan Langsa Kota, Kota Langsa, Provinsi Aceh dengan membuat plot sesuai dengan kombinasi perlakuan.

Media tumbuh dari campuran tanah dan pupuk kandang steril yang telah disaring dengan perbandingan 1 : 1. Media dimasukkan kedalam polibeg bibit ukuran 4 x $6 \mathrm{~cm}$. Biji cabai varietas Lado F1 diletakkan satu per satu per polibeg, lalu ditutup selapis tanah + pupuk kandang. Penyiraman dilakukan setiap hari pada pagi atau sore hari untuk menjaga kelembaban.

Setelah bibit memiliki 5-6 helai daun (umur 30 hari), bibit cabai dapat dipindahkan ke pertanaman. Bibit yang akan ditanam dipilih yang seragam dan sehat.Penanaman dilakukan pada sore hari dengan mengeluarkan bibit dari polibeg bibit dan memasukkannya ke dalam polibeg besar kapasitas $5 \mathrm{~kg}$. Setelah penanaman selesai, tanaman langsung disiram. Penempatan polibeg dilakukan dengan jarak tanam yang seragam pada masing-masing plot perlakuan, jarak antar plot $30 \mathrm{~cm}$ sedangkan jarak antar ulangan $50 \mathrm{~cm}$.

Inokulum jamur endofit yang digunakan adalah biakan murni hasil isolasi pada medium PDA. Setelah biakan berumur 7 hari, miselium jamur yang tumbuh pada permukaan medium PDA dikumpulkan dengan memberikan air steril sebanyak $10 \mathrm{ml}$ dan dimasukkan ke dalam tabung reaksi. Setelah itu di shaker dengan kecepatan 100 rpm selama 5 menit agar spora menyebar dalam suspensi. Untuk mendapatkan kerapatan konidia $10^{5} / \mathrm{ml}$ air dilakukan pengenceran secara bertahap. Perhitungan kerapatan konidia dilakukan dengan menggunakan haemositometer.

Aplikasi jamur endofit pada tanaman cabai dilakukan dengan beberapa metode sebagai berikut:

Benih yang akan digunakan pertamatama harus didesinfeksi dahulu dengan larutan natrium hipoklorit $1 \%$ selama 2 menit, kemudian dibilas dengan akuades steril sebanyak tiga kali. Benih selanjutnya direndam dalam suspensi konidia jamur endofit dengan konsentrasi $10^{5}$ selama 6 jam (Istikorini, 2008).

Perendaman akar dilakukan pada bibit cabai umur 30 hari setelah semai (hss) atau pada saat dipindahtanamkan ke polibeg di rumah kasa dengan cara memotong ujung rambut akar dan merendamnya pada masingmasing larutan jamur endofit dengan konsentrasi $10^{5}$ konida/ml selama 30 menit. Selama perendaman bibit diguncang di atas shaker dengan kecepatan 100 rpm selama 30 menit. Setelah itu bibit tanaman cabai ditanam kembali dalam polibeg (Istikorini, 2008).

Penyemprotan pada daun tanaman cabai dilaksanakan pada saat tanaman berumur 10 hari setelah dipindahtanamkan ke polibeg di rumah kasa yang dilakukan pada pagi hari. Penyemprotan dilakukan hingga daun basah merata. Volume penyemprotan disesuaikan dengan luas kanopi tanaman.Penyemprotan dilakukan 5 kali dengan interval waktu 1 minggu sekali

Aplikasi pada buah dilakukan satu kali yaitu setelah tanaman berbuah muda. Penyemprotan suspensi konidia jamur endofit dengan konsentrasi $10^{5} \mathrm{konida} / \mathrm{ml}$ dilakukan pada semua buah yang ada dipohon sampel dan disemprotkan sampai 
semua permukaan buah basah secara merata (Nurjanani, 2010).

Pemupukan dilakukan 1 hari setelah pindah tanam ke polibeg besar di rumah kasa, yaitu pemberian pupuk kandang sapi 100 gr/tanaman dan diulang 2 minggu sekali. Setelah tanaman cabai berumur 2 minggu di rumah kasa, tanaman diberi ajir (sokongan) sebagai penopang tanaman, agar batang tanaman cabai tidak rebah sehingga dapat memperkokoh tanaman. Penyiraman dilakukan setiap hari sesuai kondisi lapangan. Penyiangan dilakukan setiap sebulan sekali atau jika dibutuhkan untuk membuang gulma yang tumbuh.

Peubah amatan dalam penelitian ini adalah tinggi tanaman, panjang akar, berat basah akar, berat kering akar dan produksi tanaman. Tinggi tanaman diukur dari permukaan tanah sampai dengan titik tumbuh tertinggi. Pengukuran dilakukan mulai umur satu minggu setelah tanam di polibeg besar (minggu ke-5 setelah semai) dengan interval waktu satu minggu sekali sampai panen kelima.
Panjang akar diukur pada saat panen terakhir yaitu umur 19 minggu setelah tanam (mst). Akar dibersihkan dari tanah menggunakan air mengalir dan diukur dari pangkal hingga ujung akar. Berat akar basah dihitung pada saat panen terakhir yaitu umur 19 minggu setelah tanam (mst), akar dicabut lalu dibersihkan, kemudian ditimbang dengan menggunakan timbangan analitik. Berat akar kering dihitung dengan memasukkan akar ke dalam amplop dan dimasukkan pada oven dengan suhu $60^{\circ} \mathrm{C}$ selama 48 jam.

Hasil produksi buah cabai ditimbang setiap panen perpohonnya untuk memperoleh jumlah berat per gramnya. Produksi dihitung mulai panen pertama dengan ciri cabai telah berwarna merah merata, sampai dengan panen ke-5 yaitu umur 19 minggu setelah tanam (mst). Pemanenan dilakukan dengan interval waktu 5 hari sekali dengan menimbang berat buah cabai yang dipanen dari setiap tanaman perlakukan (g/tanaman) dari 3 tanaman sampel, kemudian dikonversikan ke dalam ton/ha dengan menggunakan rumus berikut :

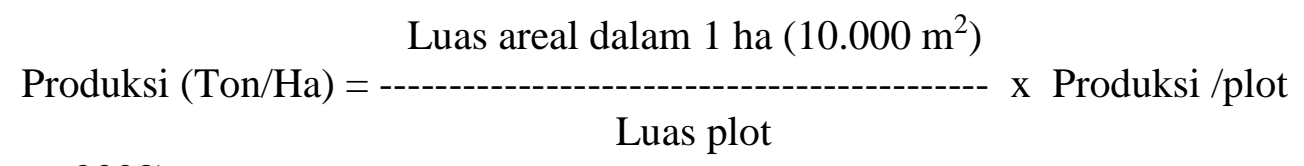

(Girsang, 2008).

Data dianalisis dengan menggunakan sidik ragam (Anova), dan dilanjutkan dengan Uji Duncan (DMRT) dengan taraf nyata $5 \%$.

\section{HASIL DAN PEMBAHASAN}

\section{Tinggi Tanaman $(\mathrm{cm})$}

Hasil penelitian menunjukkan pada umur 1, 3, 5, 7, dan 9 minggu setelah tanaman (mst) tanaman tertinggi dijumpai pada perlakuan $\mathrm{A}_{2} \mathrm{E}_{1}$ (perendaman akar dengan Penicillium sp.) yang berbeda nyata dengan semua perlakuan lainnya. Hasil ini menunjukkan bahwa Penicillium sp. yang diaplikasikan melalui akar dapat meningkatkan pertumbuhan tanaman, hal ini diduga jamur Penicillium sp. menghasilkan hormon yang dapat merangsang pertumbuhan tanaman. Yadav et al. (2011) melaporkan bahwa Penicillium citrinum strain BHUPC01 mampu menghasilkan IAA sebanyak $52 \mu \mathrm{g}$ per $\mathrm{mL}$ setelah inkubasi 3 hari pada temperatur $28^{\circ} \mathrm{C} \pm 2^{\circ} \mathrm{C}$. 
Tabel 1. Rata-rata tinggi tanaman (cm) akibat perlakuan cara aplikasi (A) dan asal isolat jamur endofit (E)

\begin{tabular}{llllll}
\hline Perlakuan & \multicolumn{5}{c}{ Tinggi tanaman $(\mathrm{cm})$} \\
\cline { 2 - 6 } & $1 \mathrm{mst}$ & $3 \mathrm{mst}$ & $5 \mathrm{mst}$ & $7 \mathrm{mst}$ & $9 \mathrm{mst}$ \\
\hline $\mathrm{A}_{1} \mathrm{E}_{0}$ & $15.00 \mathrm{ab}$ & $43.33 \mathrm{ef}$ & $69.11 \mathrm{ab}$ & $80.55 \mathrm{abc}$ & $99.89 \mathrm{abcde}$ \\
$\mathrm{A}_{1} \mathrm{E}_{1}$ & $15.89 \mathrm{bc}$ & $40.78 \mathrm{abcd}$ & $71.89 \mathrm{~b}$ & $88.11 \mathrm{~d}$ & $103.22 \mathrm{cdef}$ \\
$\mathrm{A}_{1} \mathrm{E}_{2}$ & $14.78 \mathrm{a}$ & $44.00 \mathrm{f}$ & $76.56 \mathrm{de}$ & $89.11 \mathrm{~d}$ & $101.89 \mathrm{bcdef}$ \\
$\mathrm{A}_{1} \mathrm{E}_{3}$ & $15.89 \mathrm{bc}$ & $40.67 \mathrm{abc}$ & $73.89 \mathrm{~cd}$ & $83.55 \mathrm{abcd}$ & $97.22 \mathrm{ab}$ \\
$\mathrm{A}_{2} \mathrm{E}_{0}$ & $16.44 \mathrm{cdef}$ & $42.22 \mathrm{cdef}$ & $67.89 \mathrm{ab}$ & $77.89 \mathrm{a}$ & $96.45 \mathrm{a}$ \\
$\mathrm{A}_{2} \mathrm{E}_{1}$ & $19.44 \mathrm{~h}$ & $50.44 \mathrm{~g}$ & $80.33 \mathrm{f}$ & $110.11 \mathrm{e}$ & $122.34 \mathrm{~g}$ \\
$\mathrm{~A}_{2} \mathrm{E}_{2}$ & $17.33 \mathrm{fg}$ & $43.89 \mathrm{ef}$ & $69.56 \mathrm{ab}$ & $85.56 \mathrm{~cd}$ & $99.33 \mathrm{abcd}$ \\
$\mathrm{A}_{2} \mathrm{E}_{3}$ & $16.22 \mathrm{cde}$ & $39.89 \mathrm{ab}$ & $77.00 \mathrm{e}$ & $88.33 \mathrm{~d}$ & $103.89 \mathrm{cdef}$ \\
$\mathrm{A}_{3} \mathrm{E}_{0}$ & $16.11 \mathrm{~cd}$ & $43.22 \mathrm{ef}$ & $71.89 \mathrm{~b}$ & $84.66 \mathrm{bcd}$ & $98.67 \mathrm{abc}$ \\
$\mathrm{A}_{3} \mathrm{E}_{1}$ & $17.00 \mathrm{def}$ & $42.78 \mathrm{cdef}$ & $75.11 \mathrm{de}$ & $88.45 \mathrm{~d}$ & $104.22 \mathrm{def}$ \\
$\mathrm{A}_{3} \mathrm{E}_{2}$ & $17.11 \mathrm{efg}$ & $39.56 \mathrm{a}$ & $74.33 \mathrm{cde}$ & $81.78 \mathrm{abc}$ & $99.44 \mathrm{abcd}$ \\
$\mathrm{A}_{3} \mathrm{E}_{3}$ & $17.89 \mathrm{~g}$ & $44.22 \mathrm{f}$ & $75.00 \mathrm{de}$ & $84.00 \mathrm{bcd}$ & $105.56 \mathrm{f}$ \\
$\mathrm{A}_{4} \mathrm{E}_{0}$ & $17.33 \mathrm{fg}$ & $42.67 \mathrm{cdef}$ & $69.44 \mathrm{ab}$ & $80.33 \mathrm{abc}$ & $105.22 \mathrm{ef}$ \\
$\mathrm{A}_{4} \mathrm{E}_{1}$ & $17.00 \mathrm{def}$ & $41.56 \mathrm{abcde}$ & $69.00 \mathrm{ab}$ & $79.34 \mathrm{ab}$ & $104.22 \mathrm{def}$ \\
$\mathrm{A}_{4} \mathrm{E}_{2}$ & $17.11 \mathrm{efg}$ & $43.11 \mathrm{def}$ & $71.00 \mathrm{~b}$ & $84.44 \mathrm{bcd}$ & $99.56 \mathrm{abcd}$ \\
$\mathrm{A}_{4} \mathrm{E}_{3}$ & $17.89 \mathrm{~g}$ & $42.11 \mathrm{bcdef}$ & $69.78 \mathrm{ab}$ & $86.33 \mathrm{~cd}$ & $99.56 \mathrm{abcd}$ \\
\hline
\end{tabular}

Tan \& Zou (2001) menyatakan jamur endofit memiliki kemampuan dalam menginduksi tanaman untuk menghasilkan hormon pertumbuhan. Meningkatnya pertumbuhan tanaman berkaitan dengan produksi fitohormon seperti indole-3-acetid acid (IAA), sitokinin dan hormon pemacu pertumbuhan lainnya, sebagian endofit dapat meningkatkan penambahan nutrisi seperti nitrogen dan fosfat.

Jamur Penicillium sp. juga dapat berfungsi sebagai pemacu pertumbuhan atau plant growth promoting fungi (PGPF). PGPF menggunakan salah satu dari beberapa mekanisme untuk meningkatkan pertumbuhan tanaman seperti produksi fitohormon, solubilisasi mineral dan antagonisme untuk fitopatogen (Nenwani et al., 2010). Mekanisme yang mungkin terjadi adalah jamur tersebut mempunyai kemampuan dalam meningkatkan penyediaan hara serta kemampuan dalam memacu pertumbuhan tanaman melalui produksi hormon pemacu pertumbuhan. Kelangsungan simbiosis antara akar tanaman cabai dan jamur Penicillium sp. akan berpengaruh terhadap proses-proses metabolisme tanaman, seperti fotosintesis akan berlangsung secara maksimal sehingga fotosintesis yang dihasilkan akan meningkatkan pertumbuhan tanaman.

\section{Panjang akar (cm), berat basah (g) dan berat kering akar (g)}

Hasil penelitian menunjukkan bahwa parameter panjang akar terbaik dijumpai pada perlakuan $\mathrm{A}_{3} \mathrm{E}_{1}$ dengan panjang akar $25,44 \mathrm{~cm}$. Hal ini disebabkan aplikasi Penicillium sp. melalui penyemprotan ke daun $\left(\mathrm{A}_{3} \mathrm{E}_{1}\right)$ dapat menyebabkan jamur tersebut masuk ke dalam daun melalui permukaan stomata dan hidatoda sehingga mengakibatkan kolonisasi jamur dalam ruang intraseluler jaringan daun (Beattie \& Lindaow, 1999). Diduga bahwa Penicillium sp. yang diaplikasikan melalui daun juga dapat berpindah masuk ke jaringan akar dengan aliran fotosintat melalui floem, 
kemudian Penicillium sp. akan mengkolonisasi jaringan akar sehingga pertumbuhan dan perkembangan akar dapat meningkat. Aplikasi dengan Penicillium sp.di duga juga akan memberikan pertumbuhan akar lebih luas dan panjang sehingga mendukung proses serapan hara yang juga berhubungan dengan pertumbuhan tanaman.

Hal ini sesuai pendapat Istikorini (2008), jamur endofit menginduksi tanaman cabai melalui jaringan akar dimana signal dari jamur endofit diterima oleh reseptor pada membran plasma akar bibit cabai. Interaksi tersebut menyebabkan aktivasi gengen ketahanan, selanjutnya terjadi ekspresi ketahanan. Istikorini (2008) juga menyatakan keberadaan jamur endofit dalam jaringan tanaman akar cabai dapat menyebabkan jumlah dan percabangan akar rambut serta akar lateral meningkat. Akar lateral dapat memperluas daerah penyerapan unsur hara oleh tanaman sehingga kebutuhan nutrisi lebih cepat terpenuhi dan lebih mampu meningkatkan pertumbuhan tanaman.

Berat basah dan kering akar tertinggi terdapat pada perlakuan $\mathrm{A}_{2} \mathrm{E}_{1}$ masing-masing seberat 83,89 g dan 38,64 g. Aplikasi melalui perendaman akar dengan Penicillium sp. $\left(\mathrm{A}_{2} \mathrm{E}_{1}\right)$ menyebabkan jamur tersebut masuk melalui perakaran sekunder selanjutnya berkoloni pada titik tempatnya masuk yaitu pada zona akar. Endofit kemudian hidup dalam sel, ruang interseluler atau dalam sistem pembuluh. Hifa jamur yang menempel di permukaan epidermis akar akan berperan sebagai filter pada proses penyerapan, sehingga tanaman terlindung dari zat-zat yang bersifat racun atau menghasilkan antibiotik (Prasetyoputri \& Ines, 2006). Haggag \&Mohamed (2007), menyatakan bahwa Penicillium sp. dapat bersifat

Tabel 2. Rata-rata panjang akar (cm), berat basah $(\mathrm{g})$, dan berat kering akar $(\mathrm{g})$ akibat cara aplikasi jamur endofit dan asal isolat jamur endofit

\begin{tabular}{clll}
\hline Perlakuan & \multicolumn{1}{c}{$\begin{array}{c}\text { Panjang akar } \\
(\mathrm{cm})\end{array}$} & $\begin{array}{c}\text { Berat kering akar } \\
(\text { gram })\end{array}$ & $\begin{array}{c}\text { Berat basah akar } \\
(\text { gram })\end{array}$ \\
\hline $\mathrm{A}_{1} \mathrm{E}_{0}$ & $19.56 \mathrm{bc}$ & $17.21 \mathrm{a}$ & $38.89 \mathrm{ab}$ \\
$\mathrm{A}_{1} \mathrm{E}_{1}$ & $23.22 \mathrm{efg}$ & $26.52 \mathrm{ef}$ & $56.11 \mathrm{def}$ \\
$\mathrm{A}_{1} \mathrm{E}_{2}$ & $24.33 \mathrm{efg}$ & $17.50 \mathrm{ab}$ & $42.78 \mathrm{bc}$ \\
$\mathrm{A}_{1} \mathrm{E}_{3}$ & $19.11 \mathrm{ab}$ & $18.07 \mathrm{ab}$ & $33.33 \mathrm{a}$ \\
$\mathrm{A}_{2} \mathrm{E}_{0}$ & $17.33 \mathrm{a}$ & $22.63 \mathrm{cde}$ & $49.44 \mathrm{~cd}$ \\
$\mathrm{~A}_{2} \mathrm{E}_{1}$ & $22.67 \mathrm{def}$ & $38.64 \mathrm{i}$ & $83.89 \mathrm{i}$ \\
$\mathrm{A}_{2} \mathrm{E}_{2}$ & $19.11 \mathrm{ab}$ & $26.59 \mathrm{ef}$ & $61.67 \mathrm{fg}$ \\
$\mathrm{A}_{2} \mathrm{E}_{3}$ & $21.22 \mathrm{bcd}$ & $34.78 \mathrm{hi}$ & $75.00 \mathrm{~h}$ \\
$\mathrm{~A}_{3} \mathrm{E}_{0}$ & $22.44 \mathrm{def}$ & $29.56 \mathrm{fg}$ & $60.00 \mathrm{efg}$ \\
$\mathrm{A}_{3} \mathrm{E}_{1}$ & $25.44 \mathrm{~g}$ & $31.02 \mathrm{gh}$ & $65.56 \mathrm{~g}$ \\
$\mathrm{~A}_{3} \mathrm{E}_{2}$ & $23.44 \mathrm{efg}$ & $35.62 \mathrm{i}$ & $82.78 \mathrm{hi}$ \\
$\mathrm{A}_{3} \mathrm{E}_{3}$ & $21.67 \mathrm{cde}$ & $24,52 \mathrm{de}$ & $58.33 \mathrm{efg}$ \\
$\mathrm{A}_{4} \mathrm{E}_{0}$ & $20.89 \mathrm{bcd}$ & $21.79 \mathrm{bcd}$ & $49.44 \mathrm{~cd}$ \\
$\mathrm{~A}_{4} \mathrm{E}_{1}$ & $22.00 \mathrm{de}$ & $18.82 \mathrm{abc}$ & $42.22 \mathrm{bc}$ \\
$\mathrm{A}_{4} \mathrm{E}_{2}$ & $19.44 \mathrm{abc}$ & $22.42 \mathrm{cde}$ & $51.67 \mathrm{de}$ \\
$\mathrm{A}_{4} \mathrm{E}_{3}$ & $23.78 \mathrm{efg}$ & $17.11 \mathrm{a}$ & $32.78 \mathrm{a}$ \\
\hline
\end{tabular}

antagonis melalui mekanisme yaitu mengeluarkan beberapa senyawa alkaloid seperti agroklavine dan ergometrine yang memiliki sifat anti jamur. 
Tabel 2 menunjukkan bahwa berat basah akar dapat dihubungkan dengan berat kering akar, yaitu semakin besar berat basah akar maka semakin besar juga berat kering akar. Tanaman yang berasosiasi dengan jamur endofit akan mempunyai berat akar lebih besar. Peningkatan berat basah akar karena meningkatnya pengambilan air oleh sel tanaman. Berat basah akar juga dipengaruhi oleh tinggi tanaman, semakin tinggi tanaman maka berat basah akar cabai akan meningkat. Menurut Lahadassy et al. (2007), untuk mencapai berat basah akar yang optimal, tanaman masih membutuhkan banyak energi maupun unsur hara agar peningkatan jumlah maupun ukuran sel dapat mencapai optimal serta memungkinkan adanya peningkatan kandungan air tanaman yang optimal pula. Hal ini diduga jamur endofit dapat membantu proses penyerapan unsur hara yang dibutuhkan oleh tanaman untuk proses fotosintesis dan hasil fotosintesis dapat digunakan oleh jamur untuk mempertahankan kelangsungan hidupnya.

Hubungan yang erat antara jamur endofit dan tanaman inangnya yakni transfer materi genetik satu dengan lainnya. Sementara besarnya nilai berat kering akar tanaman mencerminkan banyaknya unsur hara yang dapat diserap akar dan digunakan untuk metabolisme dalam tubuh tanaman, berat kering akar tergantung pada laju fotosintesis dan laju pertumbuhan tanaman. Unsur hara berperan untuk pembentukan sejumlah protein tertentu, yang digunakan dalam fotosintesis dan respirasi sehingga digunakan sebagai bahan penyusun biomassa tanaman yang terakumulasi sebagai fotosintat sehingga dapat meningkatkan berat kering akar cabai (Herlina \& Pramesti 2005).

\section{Hasil Produksi (ton/ha)}

Tabel 3. Rata-rata hasil panen tanaman (ton/ha) akibat cara aplikasi jamur endofit (A) dan asal isolat jamur endofit $(\mathrm{E})$
Hasil penelitian menunjukkan bahwa produksi terbesar terdapat pada perlakuan $\mathrm{A}_{3} \mathrm{E}_{3}$ yaitu sebesar 18,07 ton/ha. Hal ini disebabkan karena aplikasi melalui penyemprotan ke daun dengan jamur endofit dilakukan sebanyak 5 kali penyemprotan, ini menyebabkan jumlah endofit yang masuk ke stomata daun lebih banyak dan proses penyerapannya pun lebih cepat dibandingkan dengan perlakuan lainnya. Teknik aplikasi tersebut memberikan kesempatan lebih besar terhadap jamur endofit tersebut untuk memasuki dan mengkolonisasi jaringan tanaman. Jamur endofit yang diaplikasi dengan penyemprotan ke daun dapat meningkatkan produksi buah sekitar 52\%, hal ini diduga karena jamur endofit mampu memproduksi hormon pertumbuhan dan membantu tersedianya unsur hara sehingga dapat meningkatkan produksi. Mittal et al. (2008), mengatakan jamur endofit dapat meningkatkan pertumbuhan dengan mekanisme memproduksi fitohormon seperti Indole acetic acid (IAA) yang merupakan pemacu tumbuh tanaman.

Jamur endofit juga menghasilkan enzim-enzim pengurai yang dapat menguraikan bahan organik, sehingga melepaskan hara yang terikat dalam senyawa komplek menjadi tersedia terutama unsur N, $\mathrm{P}$, dan S. Ketersediaan hara-hara tersebut meningkatkan pertumbuhan tanaman. Peningkatan kandungan nitrogen pada tanaman dapat berpengaruh terhadap fotosintesis sehingga dapat meningkatkan fotosintat yang berpengaruh terhadap produksi buah cabai yang terbentuk(Lestari \& Indrayati 2000). Mekanisme jamur endofit dalam meningkatkan pertumbuhan dan produksi tanaman adalah dengan melarutkan fosfat dan fiksasi nitrogen (Thakiura et al., 2004). 


\begin{tabular}{ll}
\hline Perlakuan & Hasil produksi (ton/ha) \\
\hline $\mathrm{A}_{1} \mathrm{E}_{0}$ & $11.93 \mathrm{a}$ \\
$\mathrm{A}_{1} \mathrm{E}_{1}$ & $13.27 \mathrm{~d}$ \\
$\mathrm{~A}_{1} \mathrm{E}_{2}$ & $17.32 \mathrm{f}$ \\
$\mathrm{A}_{1} \mathrm{E}_{3}$ & $12.43 \mathrm{ab}$ \\
$\mathrm{A}_{2} \mathrm{E}_{0}$ & $12.34 \mathrm{ab}$ \\
$\mathrm{A}_{2} \mathrm{E}_{1}$ & $16.63 \mathrm{f}$ \\
$\mathrm{A}_{2} \mathrm{E}_{2}$ & $13.12 \mathrm{~cd}$ \\
$\mathrm{~A}_{2} \mathrm{E}_{3}$ & $13.00 \mathrm{~cd}$ \\
$\mathrm{~A}_{3} \mathrm{E}_{0}$ & $12.29 \mathrm{ab}$ \\
$\mathrm{A}_{3} \mathrm{E}_{1}$ & $16.16 \mathrm{f}$ \\
$\mathrm{A}_{3} \mathrm{E}_{2}$ & $12.53 \mathrm{bc}$ \\
$\mathrm{A}_{3} \mathrm{E}_{3}$ & $18.07 \mathrm{~h}$ \\
$\mathrm{~A}_{4} \mathrm{E}_{0}$ & $12.40 \mathrm{ab}$ \\
$\mathrm{A}_{4} \mathrm{E}_{1}$ & $15.48 \mathrm{e}$ \\
$\mathrm{A}_{4} \mathrm{E}_{2}$ & $12.66 \mathrm{bc}$ \\
$\mathrm{A}_{4} \mathrm{E}_{3}$ & $12.89 \mathrm{bc}$ \\
\hline
\end{tabular}

Terjadinya peningkatan pertumbuhan dan produksi cabai yang diinokulasi dengan jamur endofit karena endofit juga dapat mencegah infeksi patogen ke dalam tanaman. Berkurangnya infeksi patogen menyebabkan kerusakan tanaman berkurang sehingga suplai air dan hara untuk kebutuhan tanaman dapat diserap dengan baik.Widawati (2006) yang menyatakan bahwa mikroba endofit merupakan sumber genetik yang sangat penting yang dapat digunakan sebagai agens biokontrol. Selain itu, mikroorganisme endofit menghasilkan senyawa yang bermanfaat untuk tanaman inang seperti menghasilkan senyawa yang berpotensi untuk menstimulasi pertumbuhan, fiksasi nitrogen, dan menginduksi resistensi patogen. Oleh karena itu aplikasi jamur endofit dapat dipertimbangkan untuk penggunaan secara luas di lapangan sebagai agens hayati.

\section{SIMPULAN}

Jamur endofit berpotensi sebagai agens hayati. Penggunaan Penicillium sp. yang diaplikasikan melalui perendaman akar dan penyemprotan ke daun tanaman cabai memiliki potensi yang lebih baik terhadap pertumbuhan tanaman sedangkan penggunaan Geotrichum sp. yang diaplikasikan melalui penyemprotan ke daun dapat meningkatkan produksi buah cabai.

\section{DAFTAR PUSTAKA}

AVRDC. 2004. Evaluation of phenotypic and molecular criteria for the identification of Colletotrichum species causing pepper anthracnose in Taiwan. p.92-93. in AVRDC Report 2003. AVRDC, Shanhua, Taiwan.

[BPS] Badan Pusat Statistik \& Direktorat Jenderal Hortikultura. 2014. Produksi, luas panen dan produktivitas sayuran di Indonesia tahun 2013. http://www.pertanian.go.id./Indikator /tabel-2-prod-lspn-prodvitashorti.pdf [2 Juni 2014].

Beattie, G.A \& Lidow, S.E. 1999. Bacterial colonization of leaves: A spectrum of strategies. Phytopathol. 89:353-359. 
Girsang M Erik. 2008. Uji ketahanan beberapa varietas cabai terhadap serangan penyakit antraknosa dengan pemakaian mulsa plstik. [online].

Tersedia:

http://repository.usu.ac.id/bitstream/ 123456789/7706/1/09E00423.pdf.[fe bruari 2011].

Haggag, W.M \& Mohamed, A.L. 2007. Biotechnological aspect of microorganisms used in plant biological control. World Journal of Agricultural Sciences. 3(6): 771-776.

Herlina, L \& Dewi, P. 2005. Aplikasi penggunaan agen hayati Trichoderma harzianum terhadap pertumbuhan, produksi dan kualitas buah tomat, Laporan Penelitian. Universitas Negeri Semarang.

Istikorini, Y. 2008. Potensi cendawan endofit untuk mengendalikan penyakit antraknosa pada cabai (Capsicum annum L.). (PPs) Program Pasca Sarjana / S3 IPB. Diakses dari http ://www.unila.net/ 07 Maret 2012.

Ivey, M.L.L \& Miller, S.A. 2004. Anthracnose Fruit Rot of Pepper. Ohio State University Extension Fact Sheet Plant Pathology, Columbus.p.127-132.

Kilham, W. 2006. The first of the occurrence of anthracnose disease caused by Colletitrichum gloeosporoides (Penz) Penz. And Sacc. On Dragon Fruit (Hylocercus). American Journal Of Applied Science.6(5):902-912.

Kloepper, J.W. 1993. Plant growth promoting rhizobacteria as biological control agents. p. 255-274. In F.B. Meeting, Jr. (Ed.). Soil Microbial Ecology, Applications in Agricultural and Environmental Management. Marcel Dekker, Inc. New York.

Kim, K.D., Oh, B.J \&Yang, J. 1999. Differential interaction of a Colletotrichum gloeosporioides isolate with green and red pepper fruits. Phytoparasitica. 27(2):1-10.

Kirana, R. 2006. Perbaikan daya hasil varietas cabai lokal melalui persilangan antar varietas. Jurnal Penelitian Pertanian. 17:138-145.

Lahadassy, J., Mulyati, A.M \& Sanaba, A.H. 2007.Pengaruh konsentrasi pupuk organik padat daun gamal terhadap tanaman sawi. Jurnal Agrisistem, 3(6): 51-55.

Lestari, Y \& Indrayati, L. 2000. Pemanfaatan Trichoderma dalam mempercepat perombakan bahan organik pada tanah gambut. Di dalam: Prosiding Seminar Hasil Penelitian Tanaman Pangan Lahan Rawa. Balittra Banjarbaru.

Mittal, V., Singh, O., Nayyar, H., Kaur, J \& Tewari, R. 2008. Stimulatory effect of phosphate-solubilizing fungal strain (Aspergillus awamori and Penicillium citrinum) on the yield of chickpea (Cicer arietinum L. cv. GPF2). Soil Biologi and Biochemistry. 40: 718-722.

Nayaka, C.S., Shankar, U.C.A., Niranjana. S.R., Prakash, H.S \& Mortensen, N.C. 2009. Antracnose Disease Of Chili Pepper. Technical Bulletin.

Nenwani, V.P., Doshi, Saha, T\& Rajkumar, S. 2010. Isolation and characterization of a fungal isolate for phosphate solubilization and plant growth promoting activity. Journal of Yeast and Fungal Research 1(1): 009014.

Nurahmi, E., Mahmud, T\& Sylvia, R.S. 2011. Efektivitas pupuk organik terhadap pertumbuhan dan hasil cabai merah. Jurnal Floratek. 6:158-164.

Nurjanani. 2010. Pengkajian potensi beberapa isolat Trichoderma spp.dalam pengendalian penyakit 
busuk buah kakao.Prosiding Seminar Ilmiah dan Pertemuan Tahunan PEI dan PFI XX Komisariat Daerah Sulawesi Selatan. 27 Mei 2010.

Nurhayati, Umayah, A \& Silvia E.A. 2012. Aplikasi Trichoderma virens melalui penyemprotan pada daun, akar dan perendaman akar untuk menekan infeksi penyakit downy mildew pada tanaman caisin. DHARMAPALA. 4(2). 22-28.

Petrini, O. 1991. Fungal endophytes of tree leaves. In:Microbial Ecology of Leaves (Eds. Andrews, J. H \& Hirano, S. S.). Springer-Verlag, Berlin. 179-197.

Piay, S., Tyasdjaja, A., Ernawati \& Hantoro, F. 2010. Budidaya dan pasca panen cabai merah (Capsicum anuum L). Ungaran. Badan Penelitian dan Pengembangan Pertanian Balai Pengkajian Teknologi Pertanian (BP3BTP).

Prasetyoputri, A \& Ines, A. 2006. Mikroba endofit sumber acuan baru yang berpotensi. Jurnal Bio Trend. 1(2): 1315.

Syukur, M., Sujiprihati, S., Yunianti, R \& Kusumah, D.A. 2010. Evaluasi daya hasil cabai hibrida dan daya adaptasinya di empat lokasi dalam dua tahun. Jurnal Agronomi. 38(1):43- 51.

Siddiqui, I.A \& Shaukat, S.S. 2003. Endophytic bacteria: Prospects and opportunities for the bio-logical control of plant-parasitic nematodes. Nematol. Medit. 31:111-120.

Strobel, G \& Daisy, B. 2003. Bioprospecting for microbial endophytes and their natural products. Microbiol.Molec. Biol.Rev. 6(7):491-502.

Syamsudin. 2003. Pengendalian penyakit terbawa benih (seedborne deseases) pada tanaman cabai (Capsicum annuum L.) menggunakan agen biokontrol dan ekstrak botani. http://tumoutou.net/702_07134/syam suddin.htm.

Suryaningsih, E.R\& Sutarya, A.S.D. 1996. Penyakit tanaman cabai merah dan pengendaliannya. Dalam Duriat, A.S., Widjaya, A., Thomas, W.H., Prabaningrum, L. (Eds.). Teknologi produksi cabai merah. Balitsa, Lembang. hlm 64- 83.

Syukur. 2007. Pewaris ketahanan cabai (Capsicum Anuum L) terhadap antraknosa yang disebabkan oleh Colletotrichum Acutatum. Pertanian. 35(2):112-117.

Tan, R.X \& Zou, W.X. 2001. Endophytes: a rich source of functional metabolites. Nat Product Reports. 18:448-459. DOI: http://dx.doi.org/10.1039/b100918o.

Than, P.P., Prihastuti, H., Phoulivong, S., Taylor, P.W.J \& Hyde, K.D. 2008. Chili Anthracnose Disease caused by Colletotrichum spesies. J. Zhejiang. Univ. Sci. B. 9(10): 764-778.

Thakuria, D.,Talukdar, N.C., Goswami, C., Hazarika, S\& Boro, R.C. 2004. Characterization and screening of bacteria From rhizosphere of rice grown in acidic soils of Assam. Current Science. 86:978-985.

Widawati, S \& Suliasih. 2006. Augmentasi bakteri pelarut fosfat (BPF) potensial sebagai pemacu pertumbuhan caysin (Brasica caventis Qed.) di tanah marginal. Biodiversitas. 7(1):10-14.

Yadav, J., Verma, J.P \& Tiwari, K.N. 2011. Plant growth promoting activities of fungi and their effect on chickpea plant growth. Asian JBiol Sci. 4(3): 291-299.

Yoon, J.B. 2003. Identification of genetic resources, interspecific hybridization, and inheritance analysis for breeding pepper (Capsicum annuum) resistant to anthracnose. PhD Thesis, Seoul Natl Univ, Seoul. 137p 
Jurnal Pertanian Tropik

ISSN Online No : 2356-4725

Vol.4, No.2. Agustus 2017. (18) : 171- 182 